\title{
PENGARUH KUALITAS PELAYANAN DISTRIBUSI AIR TERHADAP TINGKAT KELUHAN PELANGGAN PDAM TIRTA PAKUAN KOTA BOGOR TAHUN 2015 DAN TAHUN 2016
}

\author{
R. Poppi Rustanti dan Desty Alfianti \\ Program Studi Manajemen Industri Akademi Telekomunikasi Bogor \\ pietanti@yahoo.com
}

\begin{abstract}
This study aims to identify the quality of service provided by the company, to identify the complaints handling done by the company and to analyze the effect of the service quality of the company on the complaints experienced by the customers of PDAM Tirta Pakuan Bogor City. The method used in this research is quantitative by means of survey research. This research was conducted at PDAM Tirta Pakuan Bogor City, precisely at No. Siliwangi Street. 121 Bogor 16142, West Java. The sampling technique used in this research is nonprobability sampling technique by purposive sampling. Determination of the number of samples by Gay and Diehl (1992) and Kerlinger and Lee (2000). Validity and reliability test was submitted to 30 respondents with Product Moment formula from Pearson and Alpha Cronbach. Quantitative data are presented in the form of frequency tables. The statistical test was performed with SPSS program version 20 with Rank Spearman's correlation test and statistical test of multiple regression analysis. Based on the results of research shows that the service quality of Tirta Pakuan PDAM Kota Bogor is good. This is seen from the results of the distribution of research data showing the attitude of some respondents agree with the services provided by looking at customer complaints data that can be overcome by the company. The results of multiple regression analysis showed that the overall of each of the indicator variables give effect of $19.6 \%$ to the level of complaints experienced by customers with the value of $r$ count more than 0.361 with a confidence level of 5\% and the value of cronbach alpha greater than 0, 60 .
\end{abstract}

Keywords: Quality of Water Distribution Service

\section{A. PENDAHULUAN}

Ketatnya persaingan global, tidak menutup kemungkinan semakin berkembang pesatnya perusahaan untuk terus bersaing memberikan yang terbaik demi tercapainya tujuan perusahaan dalam memperoleh profit yang sebesar-besarnya. Bagi perusahaan yang bergerak dibidang jasa tentunya memuaskan pelanggan tidak bisa diabaikan agar perusahaan tetap bertahan dan dapat bersaing dengan perusahaan lain. Dengan adanya peningkatan kualitas baik dalam kinerja maupun pelayanan memberikan dampak positif tidak hanya untuk menjaga nama baik perusahaan, juga memberikan dampak positif dalam aspek finansial perusahaan. Kesesuaian antara keinginan pelanggan dan kehendak organisasi pengelola perusahaan merupakan syarat penting keberhasilan proses operasional perusahaan. Setiap pelanggan menghendaki kepuasan maksimal dari setiap layanan yang diberikan perusahaan. Tentunya dengan kepuasan maksimal yang didapatkan pelanggan akan mampu meningkatkan kesejahteraan pelanggakepuasan pelanggan dapat memberikan beberapa manfaat, diantaranya hubungan yang terjalin dengan baik antara perusahaan dan pelanggan.

Salah satunya perusahaan penyedia jasa adalah Perusahaan Daerah Air Minum Tirta Pakuan Kota Bogor yang melayani penyediaan air minum bagi masyarakat. Tidak hanya mengacupada orientasi keuntungan saja, PDAM Tirta Pakuan juga mengacu pada orientasi sosial demi terpenuhinya kebutuhan masyarakat di wilayah Bogor akan air minum yang siap dikonsumsi. Untuk lebih meningkatkan kualitas pelayanan air minum dan memenuhi kebutuhan air minum masyarakat secara berkesinambungan sesuai standar kesehatan, berdasarkan Peraturan Menteri Kesehatan nomor 492/MENKES/PER/IV/2010 tentang persyaratan kualitas air minum dengan mengutamakan pemetaan pelayanan, mempertimbangkan keterjangkauan masyarakat, membantu mendorong pertumbuhan perekonomian daerah serta sebagai salah satu sumber pendapatan asli daerah (PAD). PDAM Tirta Pakuan memiliki tujuan untuk memberikan pelayanan dalam bidang perairminuman kepada masyarakat secara berkesinambungan yang mampu memberikan pelayanan air minum baik kepada pelanggan, non pelanggan atau pihak lain secara terus menerus dan proporsional yang 
memenuhi syarat kualitas berdasarkan Peraturan Menteri Kesehatan Republik Indonesia dengan mempertimbangkan "keterjangkauan" dalam arti disesuaikan dengan kondisi masyarakat yang ditinjau dari aspek sosial dan ekonomi dalam hal pemenuhan kebutuhan air minum.

pada orientasi keuntungan saja, PDAM Tirta Pakuan juga mengacu pada orientasi sosial demi terpenuhinya kebutuhan masyarakat di wilayah Bogor akan air minum yang siap dikonsumsi. Untuk lebih meningkatkan kualitas pelayanan air minum dan memenuhi kebutuhan air minum masyarakat secara berkesinambungan sesuai standar kesehatan, berdasarkan Peraturan Menteri Kesehatan nomor 492/MENKES/PER/IV/2010 tentang persyaratan kualitas air minum dengan mengutamakan pemetaan pelayanan, mempertimbangkan keterjangkauan masyarakat, membantu mendorong pertumbuhan perekonomian daerah serta sebagai salah satu sumber pendapatan asli daerah (PAD). PDAM Tirta Pakuan memiliki tujuan untuk memberikan pelayanan dalam bidang perairminuman kepada masyarakat secara berkesinambungan yang mampu memberikan pelayanan air minum baik kepada pelanggan, non pelanggan atau pihak lain secara terus menerus dan proporsional yang memenuhi syarat kualitas berdasarkan Peraturan Menteri Kesehatan Republik Indonesia dengan mempertimbangkan "keterjangkauan" dalam arti disesuaikan dengan kondisi masyarakat yang ditinjau dari aspek sosial dan ekonomi dalam hal pemenuhan kebutuhan air minum.

\section{B. TINJAUAN PUSTAKA}

\section{Kualitas Pelayanan}

Menururt Tjiptono (2011:80) Kualitas pelayanan jasa yaitu, tingkat keunggulan yang diharapkan dan pengendalian atas tingkat keunggulan tersebut untuk memenuhi keinginan pelanggan. dengan kata lain, ada dua faktor utama yang mempengaruhi kualitas pelayanan jasa yaitu dirasakan expected service dan perceived service. terdapat lima kriteria penentu kualitas pelayanan seperti yang diungkapkan oleh Parasuraman, Zeithaml Dan Berry (1988), dalam risetnya menemukan dan berhasil mengidentifikasi lima dimensi pokok kualitas pelayanan yang dikutip oleh Fandy Tjiptono (2016:137), yaitu :

a. Tangibles (Bukti Fisik)

b. Realibility (Keandalan)

c. Assurance (Jaminan )

d. Empathy ( Empati)

e. Responsiveness (Daya Tanggap)

2. Keluhan Pelanggan

Komplain/keluhan adalah cara untuk memperbaiki kualitas pelayanan yang diberikan perusahaan kepada pelanggan. Menurut Tjiptono (446:2016) Keluhan yaitu ungkapan kekecewaan atau ketidakpuasan.

\section{Sistem distribusi air}

Sistem distribusi air merupakan sistem yang berfungsi untuk mendistribusikan air yang telah memenuhi syarat penyediaan air bersih ke seluruh daerah pelayanan. Sistem ini merupakan sistem yang berhubungan langsung dengan pelanggan sehingga harus optimal dalam pengoperasiannya. Sistem distribusi air pompa yang membawa air yang telah diolah dari instalasi pengolahan air menuju reservoir yang kemudian dialirkan ke pelanggan, baik di pemukiman, perkantoran, dan industri lainnya yang mengkonsumsi air.

\section{Sistem Pengolahan Air PDAM Tirta Pakuan Kota Bogor}

Proses pengolahan air PDAM Tirta Pakuan Kota Bogor digolongkan menjadi dua jenis, yaitu:

a) Pengolahan Lengkap (Complete Treatment Process).

b) Pengolahan Sebagian (Partial Treatment Process).

\section{METODE PENELITIAN}

1. Teknik Pengumpulan Data

a) Wawancara

Menurut Sugiyono (2012:137) wawancara digunakan sebagai teknik pengumpulan data untuk menemukan pendahuluan mengenai permasalahan yang harus diteliti.

b) Kuesioner data yang digunakan dalam penelitian ini diperoleh melalui metode kuesioner yaitu teknik pengumpulan data yang dilakukan dengan cara memberi kuesioner atau seperangkat pertanyaan atau pernyataan tertulis kepada responden (Sugiyono, 2001)

c) Observasi 
Menurut Cristensen dalam Sugiyono (2014:196) observasi dalam penelitian diartikan sebagai pengamatan terhadap pola perilaku manusia dalam situasi tertentu, untuk mendapatkan informasi tentang fenomena yang diinginkan

d) Studi Pustaka

Teknik pengumpulan data dengan cara menggunakan literatur yang sesuai dengan tema penelitian.

\section{Teknik analisis Data}

Metode analisis data yang digunakan dalam penelitian ini adalah teknik analisis statistik inferensial. Statistik inferensial merupakan analisis data berdasarkan sampel dengan maksud untuk mengambil kesimpulan terhadap populasi. (Sugiyono, 2014:203). Dengan menggunakan metode statistik nonparametris, yaitu metode yang tidak menuntut diperlukan pengujian asumsi-asumsi, misalnya data yang akan dianalisis tidak harus berdistribusi normal. Statistik nonparametris kebanyakan digunakan untuk menganalisis data nominal dan ordinal (Sugiyono, 2014:202).

\section{Uji Instrumen}

1) Uji Validitas

Validitas yang digunakan dalam penelitian ini menggambarkan kesesuaian sebuah pengukur data dengan apa yang diukur. Valid berarti instrumen yang digunakan dapat mengukur apa yang hendak diteliti (Ferdinand, 2006). Valid menunjukan derajat ketepatan antara data yang sesungguhnya terjadi pada obyek dengan data yang dapat dikumpulkan oleh peneliti (Sugiyono, 2014:168). Pengujian validitas dilakukan kepada 30 responden yang merupakan pelanggan PDAM Tirta Pakuan Kota Bogor golongan rumah tangga. Dalam melakukan pengujian validitas, digunakan alat ukur berupa program komputer yaitu SPSS for Windows 20 dengan uji koefesien dan korelasi Pengujian instrumen. Adapun kriteria pengambilan keputusan yang digunakan pada uji validitas dengan bantuan SPSS for Windows adalah sebagai berikut:

a. Jika Sig. $\leq 0,05$ valid atau thitung $>$ t tabel maka angket tersebut dinyatakan valid.

b. Jika Sig. $>0,05$ atau thitung $<\mathrm{t}$ tabel maka angket tersebut dinyatakan tidak valid.

Penelitian dalam penelitian ini menggunakan rumus statistika Koefisien Korelasi Product Moment dari Pearson dengan rumus sebagai berikut :

$$
r=\frac{n \sum X Y-\left(\sum X\right)\left(\sum Y\right)}{\sqrt{\left(n \sum(X)^{2}-\left(\sum X\right)^{2}\right)\left(n \sum(Y)^{2}-\left(\sum Y\right)^{2}\right)}}
$$

\section{2) Uji Reliabilitas}

Reliabilitas adalah alat untuk mengukur suatu kuesioner yang merupakan alat ukur pengukuran variabel. Suatu kuesioner dikatakan reliable/handal jika jawaban seseorang adalah konsisten dari waktu ke waktu. Semakin tinggi reliabilitas, semakin stabil pula alat pengukur tersebut. Dalam perhitungan alpha, digunakan alat bantu program komputer SPSS for wimdows 20, dengan menggunakan model alpha. Suatu instrumen dikatakan reliable jika nilai cronbach alpha lebih besar dari 0,60 ( Ghozali, 2001). Rumus yang digunakan untuk menguji reliabilitas pada penelitian ini adalah rumus Alpha Cronbach sebagai berikut:

$$
\alpha=\left(\frac{k}{k-1}\right)\left(1-\frac{\sum \sigma_{b}^{2}}{\sigma_{t}^{2}}\right)
$$

3) Uji Analisis Regresi Berganda

Analisis regresi pada dasarnya adalah studi mengenai ketergantungan variabel dependen (terikat) dengan satu atau lebih variabel independen (variabel penjelas/bebas), dengan tujuan untuk mengestimasi dan/atau memprediksi rata-rata populasi atau nilai variabel dependen berdasarkan nilai variabel independen yang diketahui. (Ghozali, 2005). Untuk regresi yang variabel independennya terdiri atas dua atau lebih, regresinya disebut juga regresi berganda. Persamaan Regresi dalam penelitian ini adalah untuk mengetahui seberapa besar pengaruh variabel independen atau bebas yaitu dimensi kualitas pelayanan yang terdiri dari: Bukti Fisik (X1), Kehandalan (X2), Jaminan (X3) Empati (X4) dan Daya Tanggap (X5), terhadap Tingkat Keluhan Pelanggan PDAM Tirta Pakuan 
Kota Bogor (Y) dengan menguji pada uji t, uji f dan uji koefisien determinasi.Rumus matemastis dari regresi berganda yang digunakan dalam penelitian ini adalah :

$$
\begin{aligned}
\mathrm{Y}= & \mathrm{a}+\mathrm{b} 1 \mathrm{X} 1+\mathrm{b} 2 \mathrm{X} 2+\mathrm{b} 3 \mathrm{X} 3+\mathrm{b} 4 \mathrm{X} 4 \\
& +\mathrm{b} 5 \mathrm{X} 5+\mathrm{e}
\end{aligned}
$$

Dengan menguji pada Uji T,Uji F dan Uji Determinasi sebagai berikut:

a. Uji T bertujuan untuk mengetahui ada atau tidaknya pengaruh parsial (sendiri) yang diberikan variabel bebas (X) terhadap variabel terikat (Y).

b. Uji $\mathrm{F}$ bertujuan untuk melihat ada atau tidaknya pengaruh yag simultan (bersama-sama) yang diberikan variabel bebas $(\mathrm{X})$ terhadap variabel terikat $(\mathrm{Y})$.

c. Uji Determinasi berfungsi untuk mengetahui berapa persen pengaruh variabel yang diberikan variabel bebas $(\mathrm{X})$ secara simultan terhadap variabel terikat $(\mathrm{Y})$.

\section{HASIL DAN PEMBAHASAN}

Uji analisis regresi berganda bertujuan untuk mengetahui ada atau tidaknya pengaruh 2 variabel bebas atau lebih terhadap variabel terikat. Dalam uji regresi berganda peneliti menguji mengenai Uji T, Uji F dan Uji Koefisien Determinasi.

\section{Uji T}

Uji ini bertujuan untuk mengetahui ada atau tidaknya pengaruh parsial (sendiri) yang diberikan variabel kualitas pelayanan (X) dengan indikator (kehandalan, jaminan, bukti fisik, empati dan daya tanggap) terhadap variabel terikat (Y). dengan tingkat kepercayaan sebesar 95\%, a = 0,05 yang mana ketentuannya bahwa :

a. Jika nilai sig $<0,05$ atau $t$ hitung $>\mathrm{t}$ tabel, maka terdapat pengaruh varibel $\mathrm{X}$ terhadap variabel Y.

b. Jika nilai sig > 0,05 atau t hitung < t tabel, maka tidak terdapat pengaruh varibel $\mathrm{X}$ terhadap variabel Y.

Untuk mengetahui t tabel dapat dicari dengan rumus:

$\mathrm{T}$ tabel $=\mathrm{t}(\mathrm{a} / 2 ; \mathrm{n}-\mathrm{k}-1)=\mathrm{t}(0,05 / 2 ; 30-5-1)=0,025 ; 24$, dimana $\mathrm{k}$ adalah jumlah variabel bebas dan $\mathrm{n}$ adalah jumlah responden. Dengan melihat pada distribusi t tabel ditemukan nilai 2,064, yang merupakan nilai t tabel untuk mengetahui ada atau tidaknya pengaruh pada variabel bebas terhadap variabel terikat. Berikut merupakan hasil output uji analisis regresi berganda yang akan di

\begin{tabular}{|c|c|c|c|c|c|c|}
\hline \multicolumn{7}{|c|}{ Coefficients $^{\mathrm{A}}$} \\
\hline & \multirow[t]{2}{*}{ Model } & \multicolumn{2}{|c|}{$\begin{array}{c}\text { Unstandardized } \\
\text { Coefficients }\end{array}$} & \multirow{2}{*}{$\begin{array}{c}\text { Standardized } \\
\text { Coefficients } \\
\text { Beta }\end{array}$} & \multirow[t]{2}{*}{$\mathrm{T}$} & \multirow[t]{2}{*}{ Sig. } \\
\hline & & B & Std. Error & & & \\
\hline \multirow{6}{*}{1} & (Constant) & 6.265 & 1.509 & & 4.152 & .000 \\
\hline & Kehandalan (X1) & -.238 & .261 & -.245 & .911 & .371 \\
\hline & Jaminan $\left(X_{2}\right)$ & .025 & .261 & .028 & .094 & .926 \\
\hline & Bukti Fisik (X3) & -.300 & .372 & -.303 & .805 & .429 \\
\hline & Empati (X4) & .222 & .451 & .215 & .493 & .627 \\
\hline & $\begin{array}{l}\text { Daya Tanggap } \\
\text { (X5) }\end{array}$ & .136 & .264 & .157 & .515 & .611 \\
\hline
\end{tabular}
interpretasikan dengan melihat Tabel di bawah ini.

1. Dari data di atas dapat dilihat bahwa nilai signifikan untuk pengaruh $\mathrm{X} 1$ terhadap $\mathrm{Y}$ sebesar 0,371 $>0,05$ dan $t$ hitung sebesar - 0,911 < t tabel 2,064, sehingga dapat disimpulkan bahwa tidak adanya pengaruh variabel X1 (kehandalan) terhadap Y (keluhan pelanggan), karena niai signifikan lebih besar dari 0,05 dan $t$ hitung lebih rendah dari pada $t$ tabel.

2. Dari data di atas dapat dilihat bahwa nilai signifikan untuk pengaruh $\mathrm{X} 2$ terhadap $\mathrm{Y}$ sebesar 0,926 $>0,05$ dan $t$ hitung sebesar 0,094 < t tabel 2,064, sehingga dapat disimpulkan tidak ada pengaruh yang signifikan variabel X2 (Jaminan) terhadap Y (keluhan pelanggan), karena nilai signifikan lebih besar dari 0,05 dan $\mathrm{t}$ hitung lebih rendah dari $\mathrm{t}$ tabel.

3. Dari data diatas dapat dilihat bahwa nilai signifikan untuk pengaruh X3 terhadap Y sebesar 0,429 $>0,05$ dan t hitung sebesar $-0,805<2,064$, sehingga dapat disimpulkan bahwa tidak adanya 
pengaruh variabel X3 (bukti fisik) terhadap variabel $\mathrm{Y}$ (keluhan pelanggan), karena nilai signifikan lebih besar dari 0,05 dan t hitung lebih rendah dari t tabel.

4. dari data di atas dapat dilihat bahwa nilai signifikan untuk pengaruh variabel $\mathrm{X} 4$ terhadap $\mathrm{Y}$ sebesar 0,627 >0,05 dan thitung sebesar 0,493 < t tabel 2,024, sehingga dapat dikatakan bahwa tidak ada pengaruh variabel X4 (empati) terhadap variabel Y (keluhan pelanggan), karena nilai signifikan lebih besar dari 0,05 dan nilai thitung lebih rendah dari t tabel.

5. Dari data di atas dapat disimpulkan bahwa nilai signifikan untuk pengaruh variabel X5 terhadap Y sebesar 0,611 > 0,05 dan $\mathrm{t}$ hitung sebesar 0,515 < t tabel 2,064, sehingga dapat disimpulkan bahwa tidak ada pengaruh variabel X5 (daya tanggap) terhadap variabel Y (keluhan pelanggan) karena nilai signifikan lebih besar dari 0,05 dan t hitung lebih rendah dari t tabel.

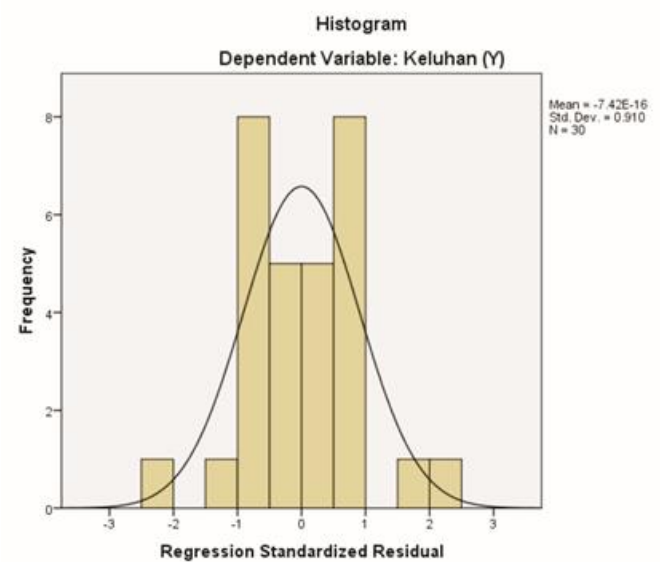

Kurva Uji T

Dari kurva di atas maka dapat disimpulkan tidak adanya pengaruh yang diberikan oleh variabel $\mathrm{X}$ terhadap variabel $\mathrm{Y}$, dimana thitung terdapat pada area hipotesis ditolak karena $\mathrm{t}$ hitung $<\mathrm{t}$ tabel, yaitu sebesar 2,064.

\section{Uji F}

Uji $\mathrm{F}$ bertujuan untuk melihat ada atau tidaknya pengaruh yag simultan (bersama-sama) yang diberikan variabel bebas $(\mathrm{X})$ terhadap variabel terikat $(\mathrm{Y})$, dengan ketentuan bahwa:

a. Jika nilai sig < 0,05 atau $\mathrm{f}$ hitung $>\mathrm{f}$ tabel maka terdapat pengaruh variabel $\mathrm{X}$ yang simultan terhadap variabel $\mathrm{Y}$.

b. Jika nilai sig $>0,05$ atau $\mathrm{f}$ hitung $<\mathrm{f}$ tabel maka tidak terdapat pengaruh yang simultan variabel $\mathrm{X}$ terhadap variabel $\mathrm{Y}$.

Untuk mengetahui $f$ tabel maka dapat dicari dengan rumus :

$\mathrm{F}$ tabel $=\mathrm{f}(\mathrm{k} ; \mathrm{n}-\mathrm{k})=\mathrm{f}(5 ; 25)$, dimana $\mathrm{k}$ adalah jumlah variabel bebas dan $\mathrm{n}$ adalah jumlah responden. Dengan melihat tabel distribusi $f$ tabel ditemukan nilai 2,60, yang merupakan nilai $f$ tabel untuk mengetahui ada atau tidaknya pengaruh yang simultan variabel $\mathrm{X}$ terhadap variabel $\mathrm{Y}$. Berikut merupakan hasil output uji analisis regresi berganda yang akan di interpretasikan dengan melihat Tabel di bawah ini.

\begin{tabular}{|c|c|c|c|c|c|c|}
\hline \multicolumn{7}{|c|}{ ANOVA } \\
\hline Mo & & Sum of & Df & Mean & F & Sig. \\
\hline \multirow{3}{*}{1} & Regression & 11.110 & 5 & 2.222 & 1.170 & $.353^{b}$ \\
\hline & Residual & 45.590 & 24 & 1.900 & & \\
\hline & Total & 56.700 & 29 & & & \\
\hline
\end{tabular}

(Sumberi Data Primer, 2017)

Berdasarkan output di atas diketahui nilai signifikan untuk pengaruh pengaruh variabel ( kehandalan (X1), jaminan (X2), bukti fisik (X3), empati (X4), dan daya tanggap (X5)) secara simultan terhadap keluhan pelanggan (Y), adalah sebesar 0,353> dari 0,05 dan f hitung sebesar 1,170 $<\mathrm{f}$ tabel 2,60, sehingga dapat disimpulkan tidak adanya pengaruh yang simultan yang diberikan 
variabel bebas terhadap variabel terikat, karena nilai signifikan lebih besar dari 0,05 dan $\mathrm{f}$ hitung lebih rendah dari f tabel.

\section{Uji Koefisien Diterminasi}

Uji ini berfungsi untuk mengetahui berapa persen pengaruh variabel yang diberikan variabel bebas $(\mathrm{X})$ secara simultan terhadap variabel terikat $(\mathrm{Y})$. berikut merupakan hasil output analisis regresi berganda yang akan di interpretsikan pada tabel 4.18 untuk mengukur koefisien diterminasi pada variabel $\mathrm{X}$ terhadap variabel $\mathrm{Y}$.

\begin{tabular}{|c|c|c|c|c|}
\hline \multicolumn{5}{|c|}{ Model Summary ${ }^{\mathrm{b}}$} \\
\hline Model & R & R Square & $\begin{array}{l}\text { Adjusted R } \\
\text { Square }\end{array}$ & $\begin{array}{l}\text { Std. Error of the } \\
\text { Estimate }\end{array}$ \\
\hline 1 & $.443^{2}$ & .196 & .028 & 1.378 \\
\hline
\end{tabular}

Dari tabel di atas diketahui nilai R Square sebesar 0,196, hal ini mengandung arti bahwa pengaruh variabel ( kehandalan (X1), jaminan (X2), bukti fisik (X3), empati (X4), dan daya tanggap (X5)) secara simultan terhadap keluhan pelanggan (Y), sebesar 19,6\%. Sehingga dapat disimpulkan walau ada pengaruh variabel bebas terhadap variabel Y namun hanya sebesar 19,6\%.

\section{E. KESIMPULAN DAN SARAN}

\section{Kesimpulan}

Berdasarkan hasil penelitian yang telah dilakukan, maka dapat ditarik kesimpulan sebagai berikut :

a. Kualitas pelayanan yang diberikan Perusahaan Daerah Air Minum Tirta Pakuan Kota Bogor menunjukan bahwa sebagian besar responden memberikan pernyataan setuju mengenai kualitas pelayanan yang diberikan baik mengenai kehandalan, jaminan, bukti fisik, empati dan daya tanggap yang diberikan perusahaan, yang artinya perusahaan mampu memberikan pelayanan yang berkualitas kepada pelanggan.

b. Sebagian besar responden memberikan pernyataan tidak setuju mengenai keluhan yang dinyatakan oleh peneliti, yang artinya perusahaan memperhatikan pelayanan yang diberikan kepada pelanggan dan perusahaan cepat dan sigap dalam menangani keluhan yang terjadi.

c. Pengaruh yang diberikan oleh variabel bebas terhadap variabel terikat menunjukkan bahwa, kualitas pelayanan yang diberikan memiliki pengaruh sebesar 19,6\% terhadap keluhan pelanggan. Yang artinya banyaknya keluhan yang diajukan pelanggan tidak mempengaruhi pelayanan yang diberikan perusahaan kepada pelanggan lainnya. Perusahaan tetap memperhatikan kualitas pelayanan yang diberikan walaupun ada atau tidaknya keluhan yang diajukan.

\section{Saran}

Berdasarkan hasil penelitian, penulis mengajukan saran yang diharapkan dapat berguna dan menjadikan bahan pertimbangan dalam pengambilan keputusan. Saran tersebut antara lain:

a. Berdasarkan hasil kuesioner, sebagian responden banyak mengeluhkan mengenai informasi yang diberikan perusahaan, banyak diantara responden yang kurang mengetahui fasilitas pelayanan apa saja yang diberikan oleh perusahaan. Informasi tersebut dapat diberikan ketika pelanggan melakukan pemasangan baru dan perusahaan memberikan informasi yang jelas terhadap permasalahan yang dialami pelanggan baik melalui media maupun interaksi langsung dengan pelanggan. Dengan informasi yang jelas maka akan meningkatkan tingkat kepercayaan pelanggan dan meyakinkan pelanggan bahwa perusahaan dapat menampung aspirasi dan keinginan pelanggan dapat dipenuhi oleh perusahaan.

b. Berdasarkan hasil penelitian yang menunjukan bahwa hubungan yang diberikan oleh kualitas pelayanan memiliki hubungan yang rendah terhadap keluhan pelanggan distribusi air. Namun kualitas pelayanan yang diberikan tentu akan berhubungan dengan indikator keluhan lainnya selain yang diteliti oleh peneliti sehingga akan menentukan tercapai atau tidaknya tujuan perusahaan.

c. Berdasarkan hasil penelitian tersebut, yang menunjukan bahwa tidak adanya satupun indikator pada kualitas pelayanan yang mempengaruhi tingkat keluhan pelanggan. Namun perusahaan 
dapat lebih meningkatkan kualitas pelayanan perusahaan kepada pelanggan, meski keluhan dapat ditangani dengan baik dan cepat, pelayanan yang baik akan mengurangi jumlah keluhan terutama pada bidang distribusi air, nilai keluhan sekecil apapun akan mempengaruhi pola pikir pelanggan dan mengurangi loyalitas yang dimiliki pelanggan itu sendiri kepada perusahaan.

\section{F. DAFTAR PUSTAKA}

Firdaus, M.Aziz. 2012. Metode Penelitian. Jelajah Nusa: Tangerang Selatan.

Ghozali, Imam. 2001. Aplikasi Analisis Multivariate dengan Program SPSS. BP UNDIP: Semarang.

Gulo,W. 2000. Metode Penelitian. Grasindo: Jakarta.

Jatnika,Hendra, 2017. Panduan Penulisan “Tugas Akhir”. Akademi Telekomunikasi Bogor: Bogor.

Priyatno, Duwi. 2013. Analisis Korelasi, Regresi, dan Multivariate dengan SPSS. Yogyakarta: Gava Media

Sugiyono. 2014. Metode Penelitian Kombinasi. Alfabeta: Bandung.

Tjiptono, Fandy dan Gregorius Chandra Edisi 4. 2016. Service, Quality and Satisfaction.Andi: Jogjakarta.

Tjiptono, Fandy dan Gregorius Chandra. 2005. Service, Quality and Satisfaction.Andi: Yogjakarta.

Agustina, Dian Vita. 2007. Analisa Kinerja Sistem Distribusi Air Bersih Pdam Kecamatan Banyumanik Di Perumnas Banyumanik (Studi Kasus Perumnas Banyumanik Kel. Srondol Wetan).Tesis Universitas Diponegoro: Semarang.

Noviani, Hardina. 2012. Analisis Penggunaan Koagulan Poly Aluminium Chloride (PAC) Dan Kitosan Pada Proses Penjernihan Air Di Pdam Tirta Pakuan Bogor. Skripsi Universitas Pakuan: Bogor.

Sutrisni. 2010. Analisis Pengaruh Kualitas Produk, Kualitas Pelayanan, Desain Produk, Harga Dan Kepercayaan Terhadap Loyalitas Pelanggan Indosat Im3 Pada Mahasiswa Fakultas Ekonomi Universitas Diponegoro Semarang.Skripsi Universitas Diponegoro: Semarang.

Peraturan Daerah Kota Bogor Nomor 2 Tahun 2014 Tentang Pelayanan Daerah Air Minum Tirta Pakuan Kota Bogor.

Peraturan Daerah Kota Bogor Nomor 30 Tahun 2011 Tentang Golongan Tarif Air Minum Tirta Pakuan Kota Bogor. Hasil Evaluasi Kerja untuk Tahun 2015 PDAM Tirta Pakuan Kota Bogor.

Hardcopy data keluhan pelanggan tahun 2014 dan tahun 2015 dari custumer information system.

Hardcopy Rekapitulasi Pekerjaan Penanganan Keluhan Pelanggan Sub Bagian Pengaliran \& Jaringan Periode Tahun 2015 dan tahun 2016

Hardcopy Company Profile PDAM Tirta Pakuan Kota Bogor. 